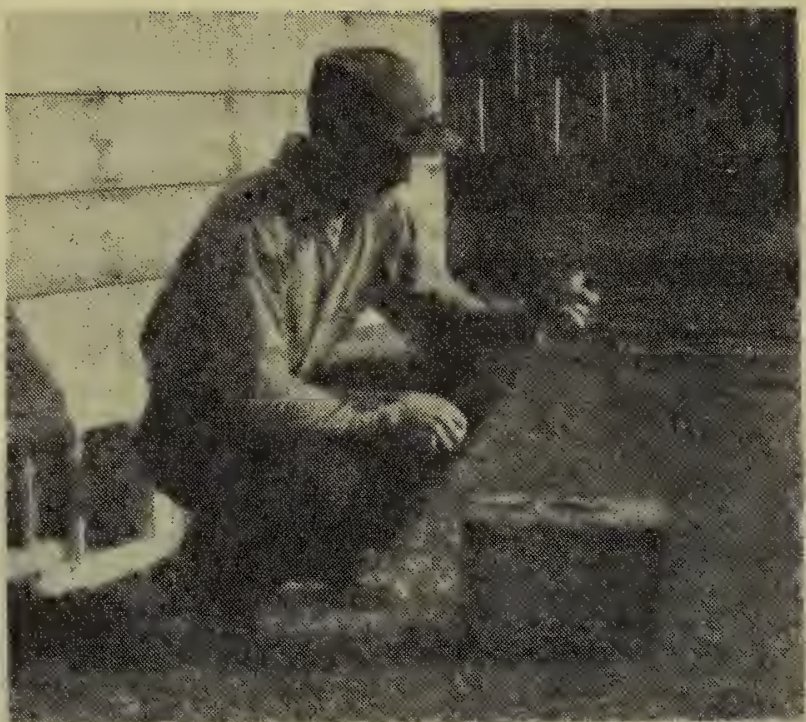

Mr. Street banding a Junco. The box is a gathering cage.

Besides supplying data to further important investigations relative to the migrations and life histories of North American birds, there are often many incidents that are only of personal interest to the bander involved. Bird Banders never know from day to day what the take or results will be, as seldom are two days alike, two seasons or two years. The migrations or movements of birds are quite often erratic, species that are abundant or easily caught one year may be unaccountably absent, or at best difficult to trap the next. Then there is the never ending attemp ts to devise methods or improve others to take greater numbers and more species. Those are the things that make bird banding so interesting.

Early this spring I trapped a male Robin already wearing a band. This bird had been banded by Billy Matthews at his station, some 3 miles distant, in 1950. I quickly discovered that this bird was mated to a female banded by me, also in 1950. The nest of this pair was not located, but in due course brought their 4 young to my banding station and all 4 were promp tly banded. Shortly after, all disappeared. However, late in July, this same pair returned with two young, which I also banded. This proved to me for the first time that a pair would remain mated for two nests in the same season. The first Vireos I ever trapped were two Blue-headed Vireos, taken two weeks apart in May. In mid June I heard a male of this species singing in the park across the street from my banding station. Several times in the next two weeks an attempt was made to locate this brilliant songster

\section{Bird Banding}

\author{
Maurice G. Street, Nipawin,
} Director S.N.H.S.

without success, his territory appeared to cover about 7 acres of mixed pine and poplar, large part of which had dense undergrowth. On July 10 th I trapped a Blue-headed Vireo, which proved to be a female with a well define d brood patch, the bird I had banded May 29th. By careful watching of the adults as they collected food for their brood, the nest containing, 2 young and one infertile egg, was found July 14th, seven feet from the ground in a poplar sapling growing in the shade of a huge Jackpine. The male Blue-headed was also wearing a band, while not proven, was undoutbably mine, also.

Finding a pair of Pigeon Hawks nesting, not over a mile from Nipawin I had great hopes of banding the brood of this little falcon, quite rare in this district. The nest was located about 30 feet up a thick spruce which had been planted some years ago about a farm home, but where now no buildings remain. The Falcons were left undisturbed until June 17th when it was decided the young, if any, would be large enough to band, Not to be however, the nest contained only one infertile egg, which the female was still brooding. Still a worthwhile nesting record for this district.

Chancing to be in a farmer's yard, with no one home, on August 7th, the farm fowl suddenly began to scurry to seek shelter in all directions. I glanced up wards to see, just in time, a bittern execute a wide circle and alight in the yard on the opposite side of a rail fence to me. Deciding here would be a bird worth banding, I picked up an old broom and started to climb the fence. Then the Bittern, seeing me for the first time, pointed its back skyward and compressing its body as only a bittern can, stayed perfectly still to escap e notice. Moving stealthly forward I got within broom range of its when it suddenly flew directly. for my face. Somehow managed to knock it down and hold it there with my broom until I caught it by the neck. Next, I (continued on next page) 
located a cardboard box and placing the bird inside began to look about for some string to tie it shut. Seeing none, I decided to turn the box upside down. In doing so the bottom fell out and only narrowly did I escape getting struck in the eye by its sharp beak before recapturing it. Just then the farmer returned home and after showing him the bird, remarked, "You did well to get that fellow, must be the one that's getting my chickens". Swallowing hard, I explained that this was a Heron, not a Hawk. Arriving back in town'I dropped the bird, still in the box, at the office. Returning a few moments later, I was surprised to see every available article, including a chair, atop the box. It seems that a Bittern, more feathers than flesh, can escape through any opening that will allow the neck and one leg to be thrust through. The bird was released wearing a band at a suitable slough.

From my kitchen window I have a string running to an ordinary droptrap, 3 feet by 4 feet and 7 inches deep. This was one of my first traps. Having been used for several years, it caught over 2500 birds, it lacked a few repairs. Accidently, one day during my absence, it was tripped and remained so until my return that evening, My wife questioned me then, as to why 1 had left two birds in it. I said I hadn't. Then she explained she had released them. Examing the trap I found two small birds still in it. Being more puzzled, I noticed a small hole near the center of the trap, barely an inch in diameter and directly over the edge of the pan of water supplied from a water drip pail above. Knowing the birds had entered the trap through the small hole to get the water, I enlarged the hole to two inches square. From August lst to August 28th, this trap had taken nearly 400 Warblers, all having entered through this small hole. Nearly 300 of these Tennessee Warblers. The remainder being made up of the following species; Black \& White, Nashville, Capemay, Myrtle, Chestnut-sided, Bay-breasted, Palm. Mourning, and Redstarts. Incidently the nearly 300 Tennessees banded during this period are more than the average banded yearly by all banders together in North America. All this by a trap accidently tripped, and a small hole.

\section{Blue Hurons - (continued from page 6)}

The young are comical looking with their long legs and big bills. When angered, they look quite fierce, stretching long necks and raising the feathers on top of their heads. till it stands straight up. They don't hesitate to strike at your either and are quite capable of giving you a nasty peck.

When we left the trees that harboured the colony we came out on a beautiful flat and there stood at least fifty Blue Herons -- a sight that is worth travelling a long distance to behold.

Alone the Byways -

\section{(continued from page 20)}

grasshoppers, it almost stepped in front of the car, but swerved in time. There was a hasty retreat to the wheat field.

In the spring we noticed a number of jack rabbits walking rather than hopping about in the fields, It was an action we hadnever seen before. They seemed to be searching carefully for something as each would stop trom time to time and then proceed. When mentioning this to a friend later, he spoke of a rumor that at this time of year the males go on such walks in search of young rabbits to destroy them. Does anyone have further information on this theory?
Sunsets along these by ways were brilliant or dull according to the cloud formations. They were al ways something to watch with an uninterrupted view as we came back to town. The speedy passing of the weeks was cause for lamentation that all too soon such rides would be over until another year.

Pretty But Somewhat Sinelly (continued from page 14)

istic smell remained. Spider-flower belongs to the Capparidaceae or Caper fanily, in which family is the Caper used to make sauce for mutton. Incidentally, when I was a youngster we made our caper sauce from Nasturtium seeds and used their leaves in sandwiches. 